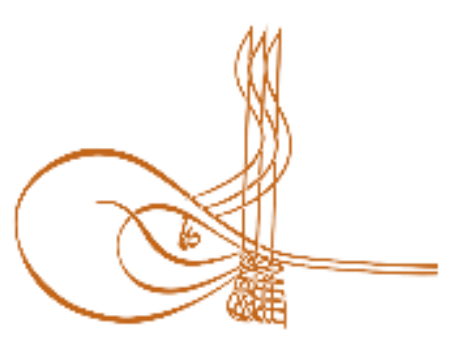

www.turkishstudies.net/turkishstudies

\section{Turkish Studies}

eISSN: $1308-2140$

Research Article / Araștırma Makalesi

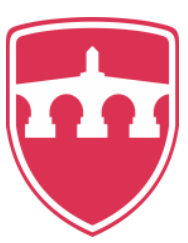

INTERNATIONAL

BALKAN

UNIVERSITY

Sponsored by IBU

\title{
Türkçenin Renk Dünyası
}

Color World Of Turkish

\author{
Arzu Şeyda Güven*
}

\begin{abstract}
Colors have always been an important part of human life. The variegation in the nature has gained value by naming these colors. Colors have been an indicator in the human life throughout history since they feature individual, social, and universal values through their aesthetic appearances. Human connection with the language takes place with the processes of perception, naming, and understanding the objects and concepts. In this context, color names can be considered as the ways of detecting and naming nature. The colors are natural indicators, while the names of the colors are linguistic and fictional indicators. The values of colors have been created and agreed on by society over time. Similar to the process of linguistic indicators being formed upon the consensus of the society, the colors became visual indicators through the same process. Language is not a static phenomenon. Therefore, it is in a constant change and development based on the time and human. Societies that constantly encounter new situations and new objects need to produce new words. In this process, some indicators fall into disuse, while new indicators enter the world of language. This is also the case with color naming. In Turkish culture, colors have an important place and value. The importance of colors in Turkish emerges from the fact that Turks have used them as value-added indicators since the earliest times. Therefore, Turkish has a rich vocabulary in terms of color names. The changes in life, the emergence of new concepts and objects and the need to name these led to a new syncretism in terms of colors. It is important to determine them in terms of the Turkish vocabulary. In this study, the current color names in the production world were examined through a simultaneous method. The color names that were used particularly in clothing, personal care, fabric, interior and exterior paints were identified and evaluated.
\end{abstract}

Structured Abstract: Colors have always been an important part of human life. The variegation in the nature has gained value by the naming of these colors. The fact that each color has a name and value is related with the significance that human attributes to the color. Colors have been an indicator in the human life throughout history since they feature individual, social, and universal values through their aesthetic appearances. Individual and social values are also attributed to the colors, which have universal values. Human connection with language takes place with the processes of perception, naming, and understanding the objects and concepts. Color names, in this context, can be considered as the ways of detecting and naming nature. The colors are natural indicators, while the names of the colors are linguistic and fictional indicators. The values of colors have been created and agreed on by society over time. Similar to the process of linguistic indicators being formed upon the consensus of the society, the colors became visual indicators

\footnotetext{
* Dr. Öğr. Üyesi, Kafkas Üniversitesi, Fen-Edebiyat Fakültesi, Türk Dili ve Edebiyatı Bölümü Asst. Prof. Dr., Kafkas University, Faculty of Science and Letters, Department of Turkish Language and Literature ORCID 0000-0002-1363-0752 arzuseyda@mynet.com

Cite as/ Atıf: Şeyda Güven, A. (2020). Türkçenin renk dünyas1, Turkish Studies, 15(2), 1343-1358. https://dx.doi.org/10.29228/TurkishStudies.40487

Received/Geliş: 09 January/Ocak 2020

Accepted/Kabul: 25 April/Nisan 2020

Copyright (C) MDE, Turkey

Checked by plagiarism software

Published/Yayın: 30 April/Nisan 2020

CC BY-NC 4.0
} 
through the same process. In Turkish culture, colors have an important place and value. The importance of colors in Turkish emerges from the fact that Turks have used them as value-added indicators since the earliest times. Therefore, Turkish has a rich vocabulary in terms of color names. One of the leading indicators of the significance of the colors in Turkish is the fact that they were included in the Orkhon Inscriptions, which are the oldest written Turkish documents.

In our study, it was determined that the highest number of color names are related to green and blue in Turkish. It is a fact that this number will further increase when all Turkish dialects and periods are examined. The fact that naming is related to the way the world is perceived is also the reason of why mostly green and blue tone distinctions exist in Turkish.

Language is not a static phenomenon. Therefore, it is in a constant change and development based on the time and human. Societies that constantly encounter new situations and new objects need to produce new words. In this process, some indicators fall into disuse, while new indicators enter the world of language. Language can be defined as a human consumption and production process. Naming concepts and objects in the world of thought is actually a production of knowledge at some point. It is important to determine them in terms of Turkish vocabulary. It's against the world of thought to make do with what exists, without forming new names. At this point, Turkish offers the opportunity to create an infinite syncretism in terms of color names. New color names are being created today through derivation, conjunction, and borrowing.

Turkish has a rich vocabulary concerning the color names. In this vocabulary, it is observed that there are not only Turkish patterns but also patterns created from words of foreign origin. The concretization characteristic of Turkish goes for the color naming as well. Detailed naming based on the main color is applied today as it was in the past. The changes in life, the emergence of new concepts and objects and the need to name these led to a new syncretism in terms of colors.

In this context, it is a reality that there is an effective use of language in color naming. Especially in today's world of production, it would not be wrong to consider the created color names as promotional texts/titles. These examples of syncretism also bear the traces of the poetry language. In particular, the connotation and emotion values of words are among the possibilities of language usage, which is frequently used in color naming.

Today, the increase of production in the human world, developing technologies, and social changes are among the important factors in color naming. In our day, especially in all areas for consumers, the effects of colors on human beings are taken into account, and the brands and products are always offered to the consumer with the help of colors. Visual attractiveness is used in all kinds of technological products as well as their quality and functions. It is observed that the choice and naming of colors are of significant importance in certain domains such as technological products, clothing, personal care, and architecture. It is because the preferred colors reflect the preferences of individual, and at some point, the inner world of the individual. Aesthetic appearance has become even more important with the help of colors in all areas with production. Each status of trade is a process of communication.

The need of language is the need of human. The naming of what exists in the human world is by human nature concerning interpretation. This results in the continuous development and change of language. In Turkish, there are many different types of syncretism and borrowing in color naming. For example, it is observed that the name of a season, a subject, a natural event, a historical period, or a place is used today as a color name. However, such color names have a more limited usage area. This is due to the facts that these patterns are not generalized, they have a limited area of dissemination, and they are given as a name for only one color. Naturally, as the usage areas of such patterns expand, they may also become generalized. In this context, depending on the need and usage, the society will decide over time which of these naming will be permanent or temporary indicators. However, although their areas of usage are limited, these patterns have taken their places in the Turkish vocabulary.

Considering from the point of gender, it is observed that the color and name of the color of the product are as important as the quality of the product in clothing and personal care products for women. This has led to the proliferation of the differentiation of colors in these areas, and consequently, the formation of namings in many different forms. Naturally, this is a positive aspect of Turkish. The new types of syncretism can be considered as an indication of the richness of Turkish and the power of conceptualization.

Turkish Studies, 15(2) 
In this study, the names of colors used and created in Turkish were emphasized in a simultaneous method. A review was conducted on current color names in the production world. In particular, the names of the colors used in clothing, personal care, fabric, interior and exterior paints were tried to be identified and evaluated.

Keywords: Turkish, Language, Culture, Color, Naming.

Öz: Renklerin insan yaşamında her zaman önemli bir yeri olmuştur. Doğada var olan çok renklilik, insanın bu renkleri adlandırmasıyla değer kazanmıştır. Renkler, estetik görünümleri yoluyla bireysel, toplumsal ve evrensel değer yüklenmeleri sonucunda tarih boyunca insan yaşamında birer gösterge olarak yer almışlardır. İnsanın dille olan bağlantısı, nesne ve kavramları algılama, adlandırma, anlamlandırma süreçleriyle birlikte gerçekleşir. Renk isimleri de bu bağlamda doğayı algılama ve onları adlandırma biçimleri olarak değerlendirilebilir. Renkler doğal göstergeyken renk adları; dilsel, kurmaca göstergedirler. Renklerin değerleri, zaman içerisinde toplum tarafindan oluşturulmuş ve üzerinde uzlaşmaya varılmıştır. Dilsel göstergelerin toplumun uzlaşması sonucunda gerçekleşmesi gibi renklerin birer görsel gösterge olmaları da aynı süreçten geçmiştir. Dil, durağan bir olgu değildir. Bu sebeple insana ve zamana bağlı olarak değişim ve gelişim içerisindedir. Sürekli yeni durumlarla, yeni nesnelerle karşılaşan toplumlar, yeni sözcükler üretme ihtiyacı duyarlar. Bu süreçte bazı göstergeler kullanımdan düşerken yeni göstergeler de dilin dünyasına girer. Renk adlandırmalarında da durum böyledir. Türk kültüründe renklerin önemli bir yeri ve değeri vardır. Türkçede renklerin önemi, Türklerin en eski zamanlardan itibaren onları değer yüklenmiş birer gösterge olarak kullanmaları dolayısıyladır. Türkçe, renk adları açısından zengin bir söz varlığına sahiptir. Yaşamın değişmesi, yeni nesnelerin ortaya çıkması ve bunların renklerinin daha ayrıntılı adlandırılması gerekliliği, renk adları açısından da yepyeni bağdaştırmaların ortaya çıkmasını sağlamaktadır. Türkçenin söz varlığı açısından bunların belirlenmesi önem taşımaktadır. Bu çalışmada eş zamanlı bir yöntemle üretim dünyasındaki güncel renk adları üzerinden inceleme yapılmıştır. Özellikle giyim, kişisel bakım, kumaş, iç ve dış cephe boyalarında kullanılan renk adları tespit edilmeye ve değerlendirilmeye çalışılmıştır.

Anahtar Kelimeler: Türkçe, Dil, Kültür, Renk, Adlandırma.

\section{Giriş}

Güncel Türkçe Sözlük’te “Cisimler tarafindan yansılanan ışı̆̆ın gözde oluşturduğu duyum." olarak tanımlanan renk kavramının insan yaşamında her zaman önemli bir yeri olmuştur.

“Hope ve Walch'a göre (1990: 286) insanoğlunun görme duyusu yaklaşık 10 milyon renk tonu ve nüansi ayırt edebilmektedir. Bu, renklerin sayısinın hemen hemen insanoğlunun tanıdığ varlıkların toplamına karşılık geldiği anlamına gelir. Insanoğlunun doğduğu andan beri renklerle olan kadim tanışıklığ yaşadĭ̆ sürece de devam eder. Renkler insanın dünyayı ve diğer birçok varlı̆̆ ya da kavramı algılamasında ve kavramlaştırmasında ona hayatı boyunca rehberlik eder. Varlıkların insanın dikkatini ilk önce renkleriyle çektiği, onların algilanmasında ve kavramlaştırılmasında diğer özelliklerinin sonradan belirleyici olduğu ileri sürülebilir. Insanoğlunun dolaylslyla nesneleri önce renkleri aracılı̆glyla kategorize ettiği ve bir cismi diğer cisimden öncelikle renkleriyle ayrıştırdı̆̆ı söylenebilir. Bu açıdan ilk ve en büyük kavramsal kategorinin renk kategorisi olduğu iddia edilebilir." (Doğan, 2015: 12-37)

Doğada var olan çok renklilik, insanın bu renkleri adlandırması ve hayatına katmasıyla değer kazanmıştır. Her rengin bir adının ve bir değerinin olması, insanın ona verdiği önemle ilintilidir. Renkler, estetik görünümleri yoluyla bireysel, toplumsal ve evrensel değer yüklenmeleri sonucunda tarih boyunca insan yaşamında birer gösterge olarak yer almışlardır. Doğada var olan renkler değişmezken renk değerleri, toplumdan topluma değişebilmektedir. Bu durum, insanların renklerle olan yaşantıları sonucuyladır. Bu bağlamda renklere atfedilen değerlerde bir ortaklık olabileceği gibi farklılıklar da söz konusu olabilmektedir. 
"Gösteren ve gösterilen birbirlerine bă̆ıml olarak bir dildeki dilsel göstergeyi oluştururlar. Bir gösterenin gösterileni yoksa bu ses grubu bir gösterge değildir. Diğer yandan benzer zorlukları öbür gösterge türlerinde de görmek olasıdır. Siyah göstergesi, Avrupa halkı için yası belirtirken, Yeni Kaledonya halkı için beyaz renk yası belirtebilir... Avrupalılar için beyaz, ışık, sevinç ya da gençlik rengiyken, Çin'de yas rengidir. Beyaz İslam geleneğinde ışı̆̆ın, parlaklı̆̆ın; Hristiyan sanatında inancın; Kara Afrika inançlarında ise ölümün simgesidir. Ya da siyah, İslam ve Hristiyanlıkta bu dünyanın geçiciliğinden vazgeçip inanca slğınmanın (örneğin din adamlarl ve Mevlevilerin siyah mantolart) simgesidir." (Günay, 2013: 212)

Renklerin adlandırılmaları gibi kültürel gösterge değerleri de zaman içerisinde toplum tarafından oluşturulmuş ve bu değerlerin üzerinde uzlaşmaya varılmıştır. Dilsel göstergelerin toplumun uzlaşması sonucunda oluşmaları gibi renklerin kültürel değer yüklenmiş birer görsel gösterge olmaları da aynı süreçten geçmiştir:

"Renklere anlam yükleme her dönemde ver her alanda olmaktadır. Felsefede, ilk çă̆ filozoflarından Empedocles ve başka bazı filozoflar dünyayı oluşturan dört temel öğeye farkl renkler vermişlerdir. Empedocles'e göre hava siyah, su beyaz, toprak sarl, ateş kırmızı; Aristo'ya göre hava beyaz, su beyaz, toprak çok renkli, ateş sarıdır. Buna karşın resim kuramcısı Leon Battista Albert, havayı mavi, suyu yeşil, toprağı bej, kül rengi, ateşi de kırmızı olarak algılamıştır.” (Günay, 2013: 212)

İnsanın dille olan bağlantısı, nesne ve kavramları algılama, adlandırma, anlamlandırma süreçleriyle gerçekleşir. Bu noktada dil, insanın dünyasında var olan nesne ve kavramlarla olan iletişimini de gerçekleştiren bir olgu olarak karşımıza çıkar. Bir dilin söz varlığı da bu yollarla oluşur.

"Söz varlı̆̆l, sadece bir dilde bir takım seslerin bir araya gelmesiyle kurulmuş simgeler, kodlar -ya da dilbilimdeki terimiyle göstergeler- olarak değil, aynı zamanda o dili konuşan toplumun kavramlar dünyasl, maddi ve manevi kültürünün yansitıclsl, dünya görüşünün bir kesiti olarak düşünülmelidir." (Aksan, 2018: 15)

Renk isimleri de bu bağlamda bir toplumun doğayı algılama, adlandırma ve anlamlandırma biçimlerinden biri olarak değerlendirilebilir. Renkler doğal göstergeyken renk adları; dilsel, kurmaca göstergelerdir. "Yeryüzündeki renkler aynı olduğu halde bunların adlandirılışı ve kapsamları dilden dile değişir." (Aksan, 2018: 16) Her toplum, yaşamda bulunan her şeyi kendi algılamasına göre adlandırır. "Her dilin kendine özgü yanları vardır. Oubanguilerin dili Sangoda üç renk vardır: Vulu (beyaz), vuko (mavi, siyah, gri, açık kestane rengi) ve bengmbwa (sarı, koyu kestane, turuncu, kırmızı, kızıl). Bir başka dilde renklerin ayrımı çok fazla olabilir." (Günay, 2013: 21) $\mathrm{Bu}$ bağlamda değerlendirildiğinde Türk kültüründe dolayısıyla Türk dilinde renklerin önemli bir yerinin, değerinin ve buna bağlı olarak ayrımının da çok olduğu görülmektedir. Türkçenin renk dünyası, doğayı algılama, onu biçimlendirme ve değerlendirme süreçleriyle birlikte uzun tarihî süreç içerisinde zenginleşmiş ve renkler, her dönemde kültürel bir öneme sahip olmuştur:

\begin{abstract}
"Türkler zevk, düşünce ve inanışlarına göre bazı renkleri sevip, onları uğurlu saymışlardır. Hattâ bazen bir renge ilahî bir boya da vermişler ve onu Tanrı'nın rengi gibi kabul etmişlerdir (Gök rengi gibi). Bazen de bir rengi uğursuzluk timsali gibi görmüşler ve ona karşı kuşku ve nefret beslemişlerdir; meselâ kara ve sarı renkleri gibi. Bazı renkler aynı zamanda bir semti veya büyüklük ve azameti temsil etmiş ve böyle bir duygu ve düşünce ile dăglarl da renklerle adlandırmışlardır; meselâ Akdeniz, Karadeniz, Karadă̆, Karabă̆ gibi." (Hey’et, 1996: 55-56)
\end{abstract}

Türkçede renklerin önemi, Türklerin en eski zamanlardan itibaren onları değer yüklenmiş birer gösterge olarak kullanmaları dolayısıyladır. Günlük yaşamın içinde yer alan renkler, Türk kültüründe bilinen en eski eserlerden elde edilen bilgilere göre özel bir yere sahiptir. "Giysilerde, takılarda, bayraklarda, hall, kilimlerde kullanılan renkler" (Küçük, 2010: 185-210), her dönemde Türkler için kültürel bir gösterge değeri taşımışlardır. 
Dil; kültürün oluşturucusu, aktarıcısı olarak yaşantıda var olan her öğeyi kendi dünyasına katar. Doğada var olan renklerin Türk düşünce dünyasında kültürel bir göstergeye dönüşmesi, birçok alanda kullanılması nedensiz değildir. Türk düşüncesinin, yaşam biçiminin yansıması olan Türk kültüründe renkler, toplumsal hayatın içerisine katılmış ve ortak algılama değeri kazanmıştır. "Türkler, hayatlarının her safhasında renkleri kullanarak onları siradanlıktan uzaklaştırıp; manevi boyutlar kazandırmışlar, her türlü his ve davranışlarını renklerle ifade edebilmişlerdir. Teşkilâtçı bir millet olan Türklerin kurduklart devletlerinin siyaset tarihlerinde renklerin oynadıklart fonksiyonlar oldukça kayda değerdir." (Yıldırım, 2012: 198)

Türk düşüncesinde renklerin öneminin en büyük göstergelerinden biri, Türkçenin yazılı en eski belgeleri olan Orhun Yazıtları'nda yer almalarıdır. Orhun Yazıtları'nda geçen renk adları "kara, yagız (yağız, siyah),ak, ürün (beyaz), kızıl, yaşıl (yeşil) sarıg (sarı) kök (mavi),boz, torug (doru) "dur. (Ercilasun, 2016: 383)

“...Türkçenin elimizdeki en eski belgelerinde bu renk adları değişik köklere bağll, daha önemlisi, değişik anlatım yollarına giden adlandırmalara tanık olacak biçimde göze çarpar: yaşıl ('yeşil' Kültigin yazıtt, doğu, 17); kök ('mavi', aynı yer, doğu, I); boz (ayn yer, doğu, 32), sarı ('sarı', Tonyukuk yazıtı, güney, 48). Bunların yanı sıra, yazıtların sinırl konularına- kisa anlatım zorunluluğuna karşın ak, kara, kızıl yegren, yağız gibi adlar da bol bol kullanilmaktadır." (Aksan, 2004: 121)

Mitolojik olarak da değer taşıyan renkler, Türk mitolojisinde de önemli bir yere sahiptir:

"Eski Türk mitoloji-kozmonik dünya bakışında rengler önemli rol oynuyor. Ateşe, oda inam, Gök Tanrı'ya inam, yuğ ve yum ritual, bayram gelenekleri simgeleri direkt veya dolaylı şekilde renglerle bağlldır. Eski Türklerin mitoloji inamınca yeryüzünde hayır, bereket, ışıg, Tanrı Ülgen'le, tüm bedhahlig, habislig, kötülük Erlik'le bağlldır. Ülgen'e beyaz-ak, Erlik'e siyah, koyu, kara rengli kurban kesilirmiş. Ak rengin Tanrl'ya aid olması esatir ve efsanelerde geniş yayllmış." (Nerimanoğlu, 1996: 68-69)

Türkçenin en önemli eserlerinden biri olan Dede Korkut Kitabı'nda da renkler, yine çeşitli duygu ve düşünce değerlerine sahip göstergeler olarak karşımıza çıkmaktadır. Bu göstergeler; kutsallık, uğur-uğursuzluk gibi toplumsal algılama biçimlerini de yansıtmaktadır:

"Ak, Boz, Ak-Boz renglerinin ululug, kutsalltg anlamı "Kitabi- Dede Korkud"dan getirdiğimiz şu parçada tam ifadesini buluyor: "Ak Kayanın kaplaninin erkeğinde bir köküm var... Ak sazın aslanında bir köküm var... Ak Sungur kuşu erkeğinde bir köküm var. Yine "Dede Korkud"da "Dirse Han oğll Buğaç Boyu"nda geçen "Bir yere ak otă̆, bir yere kizll otağ, bir yere kara otağ kurdurmuşdl. "Kimin ki oğlı kizl yok, kara otağa kondurun, kara keçe alttna dössen, kara koyun yahnisinden ögine getirün. Yerse yesin, yemezse, tursun, getsün, demişdi. "Oğlı olanı ak otağa, kızı olanı kızıl otağa kondurın. Oğll-kızı olmayanı Allah-Teala karğayıbdır, biz dahı karğarız bellü bilsün" demiş idi." (KDG.34) Şu reng sembolleri eski inanışın 'adet ve ritualdakı in'ikasıdır." (Nerimanoğlu, 1996: 68-69)

Renkler, gerçek dünyadan kurmaca dünyaya dil aracılığı ile aktarılmaktadır. "Hiçbir öğenin nedenli olmadığı dil yoktur. Her öğenin nedenli olduğu bir dil düşünebilmek ise dilin tanımı gereği olanaksızdır." (Saussure, 1998: 194) Bu bağlamda Türkçede türetme, birleştirme, aktarma ve alıntılama yoluyla gerçekleştirilen renk adlandırmaları da diğer nesne ve kavram adlandırmalarında olduğu gibi ikinci derece nedenliliğe sahip toplumun izini taşıyan, onu yansıtan birer gösterge niteliği taşımaktadır. Türkçede yeşil sözcügünün "yaş" kökenli olması gibi. Yavruağzl, tavşankanı, kavuniçi, buz beyazı, su yeşili, çam yeşili, bebek mavisi vb. örneklerinde olduğu gibi renk adlandırmaları, bir nedenlilik özelliği taşımaktadır. Türkçede somutlaştırma işlemi, nedenlilik taşıyan birçok renk adı için geçerli bir özellik olarak karşımıza çıkmaktadır:

“Türkçenin söz varlı̆̆ında, renk adlarını içeren sözcüklerin sayısı oldukça geniş bir yer tutmaktadır. Türkiye Türkçesinde renk adları, geniş kullanım yelpazesi, anlam alanları ve 
türetme, birleştirme gibi işlemler sonucu kazandlkları somutlukla özellikle dikkat çekicidir. Örneğin yavruă̆zl, gülkurusu, saman sarlsı, orman yeşili, güvercinboynu gibi renk adları; en temel özelliği soyutluk olan renk adlarının aksine somutlaşmıştır." (Bayraktar, 2014: 179-180)

Somutlaştırma işlemi sonrasında oluşturulan renk adları, daha belirgin bir çağrışım değeri taşıyan göstergelerdir:

\begin{abstract}
"Soyut adlar içinde değerlendirilen renk adlarl, Türkçede de genel itibariyle soyut ad özelliği göstermekler birlikte sıklıkla somutlaşma eğilimi gösterir. Söz gelimi, orman yeşili renk adı yeşile göre, gökyüzü mavisi maviye göre daha somuttur. Bunların yanı sıra kavuniçi, yavruağzı, portakal rengi, kurşunî, vapurdumanı grisi gibi renk adlarındaysa somutlaşma daha da belirginleşmiştir.” (Bayraktar, 2017: 71)
\end{abstract}

Somutlaştırma, bir noktada canlı anlatım demektir. Gözle görülen, bilinen bir nesne ya da varlığın rengine dayandırılarak oluşturulan bu anlatım biçimi, Türkçede çok renkli, ayrıntılı bir renk ayrımının oluşma sebeplerinden biri olarak değerlendirilebilir: "Türkçe yalnız kök (gök, mavi), yaşıl (yeşil), kızıl, sarıg (sarl) gibi ayrı köklerden oluşmuş ana renkleri içermemekte, ayrıntıya inerek çok değişik renk tonlarını da canlı biçimde adlandırabilmektedir." (Aksan, 2018: 65) Aksan'ın sözünü ettiği canlı anlatımı yeşil üzerinden değerlendirdiğimizde doğada var olan ton ayrımının Türkçeye yansımasını şu yapılarla örneklendirebiliriz:

Bambu yeşili, buz yeşili, buzlu yeşil, cam yeşili, ceviz yeşili, çağla yeşili, çam yeşili, çayır yeşili, çifttik yeşili, çiğ damlası yeşili, çim yeşili, çimen yeşili, çit yeşili, defne yeşili, deniz yeşili, elma yeşili, fistık yeşili, haki yeşil, ısırgan yeşili, kına yeşili, kivi yeşili, limon yeşili, makine yeşili, elektrik yeşili, mint yeşili, nane yeşili, Nil yeşili, orman yeşili, ördekbaşı yeşili, petrol yeşil, pudra yeşili, sarmaşık yeşili, su yeşili, şişe yeşili, Tuna yeşili, türbe yeşili, yă̆ yeşili, yaprak yeşili, yayla yeşili, yonca yeşili, yosun yeşili zeytin yeşili, zümrüt yeşili.

Çalışmamızda Türkçede en çok yeşil ve maviyle ilgili renk adının olduğu tespit edilmiştir. $\mathrm{Bu}$ sayının Türkçenin tüm dönem ve lehçeleri incelendiğinde daha da artacağ bir gerçektir. Adlandırmaların dünyayı algılama biçimiyle ilintili olma gerçeği, Türkçede en çok yeşilin ve mavinin ton ayrımının dolayısıyla adlandırmasının var olmasının sebebi olarak değerlendirilebilir. "Yeşille ilgili olarak konuya baktı̆̆ımızda ise, Türk mitolojisinde hayır ilahı Ülgen'in koruyucu ruh olarak kabul edilen yedi oğlundan birinin adının Yaşıl olduğunu görmekteyiz. Yaşıl, yaş olan, yani yeşeren, biten, topraktan çıkan şeylerin adıdır." (Genç, 1996: 41) Yeşil, doğadaki bitki canlılığının bir göstergesidir. Doğada var olan canlılığın sahip olduğu renk alanı çeşitliliği, Türkçenin söz varlığına da aynı çeşitlilikte yansımıştır.

\footnotetext{
"Yeşil veya yaşll renk, mavi ve sarı rengin terkibinden meydana gelir. Sarı renk sicaklı, mavi renk de sakinlik ve huzuru yeşil renge vermişlerdir. Yeşil renk tabiatta ağaçların ve bitkilerin sembolüdür. Bitkilerin göverme ve büyümelerine sebep güneş ışı̆̆ (sarı) ve sudur (mavi). Yeşil bitki genç ve diridir. Bu yüzden yeşillik, gençlik ve hayat nişanıdır." (Hey’et, 1996: 59)
}

Dede korkut Kitabında ise yeşil, "yeşermek gögermek" olarak geçer: "Kaba ăgaçda tal budağun kurımış-idi yeşerüp gögerdi ahır" (Ergin, 2016: 227) yerini almıştır:

Gök rengi olan mavi, yine insanın onu algılaması ve değerlendirmesiyle renk dünyasında "Gök ve mavi, gök ve suyun simge ve alâmetidir. Gök ve su insanllk tarihinde mukaddes
sayllmıştır. Gök rengi sonsuzluğu, türeyişsi, emniyet ve huzuru telkin eder ve sinirler için
kırmızının aksine olarak sükûn ve huzur verir. Gök rengi dostluk, sadakat, vefa,
aydınlık, temizlik ve ruhanîlik sembolüdür. Gök renginin Türklerde hudutları geniştir;
göğermek, yeşermek, yani yeşillik de buna dâhildir." (Hey'et, 1996: 59) 
Mavinin Türk kültüründe yüklendiği değerin en önemli göstergesi, "Gök Tengri”" bağdaştırmasıdır. Bu bağlamda Türk kültüründe kutsallık değeri de yüklenen gök renginin Türklerin rengi olduğunu söylemek de yanlış olmayacaktır:

\begin{abstract}
"Türklerin kendi sembolleri olan kutsal kurda "Kök-Böri", yani Gök Kurt demelerinin de bir sebebi vard. Kök, yani gök, göğ̈̈n rengi olan mavilik idi. Aslinda Türkler göğe Kök-Tengri, yani mavi gök derlerdi. Bugünkü Türkçemizde kullandı̆̆ımız "gök" sözü, göğ̈̈n renginden başka bir şey değildi. Gök renk, kutsal göğ̈̈n olduğu kadar, Tanrı’nın da bir sembolü idi. Bir şeyi gök rengine büründürmek veya gök sözü ile beraber söylemek, o şeyi kutsal saymak veya aralarında Tanrı ile ilgili bir băg kurmak isteğinden ileri gelmeli idi." (Ögel, 1998: 42) "Sonralar bu gök sifatl, "ihtiyarllk ve tecrübeliliğin" ifadesi ve karşıllğ̆ olarak kullanılmıșt.." (Ögel, 1998: 134) "Yakutlarda Ürüng, yani ak renk kutsallı̆̆ın bir ifadesi idi." (Ögel, 1998: 101) "Çingiz-Han'ın babası Yesügey'in de gözleri koyu mavi (Şehlâ) idi. Bunun için de ona Borçikın lakâbı takalmıştl. Bir insanin gözlerinin bu renkte olmasl, onun gelecekte büyük bir adam olacağına bir delilmiş. " (Ögel, 1998: 135)
\end{abstract}

Türkçede mavi tonlarının somutlaşma sürecinde de yine zengin bir adlandırma dünyası söz konusudur. Mavinin doğada var olan ton ayrımının Türkçeye yansıması noktasında aşağıda verilen yapılar, bu renge yaşama dayalı ad verme örnekleridir:

Bebek mavisi, Bodrum mavisi, boncuk mavisi, bulut mavisi, buz mavisi, camgöbeği mavi, cennet mavi, çapa mavi, Çin mavisi, çivit mavisi, deniz mavisi, duman mavisi, Ege mavisi, elektrik mavisi, gece mavisi, gök mavi, gökyüzü mavisi, inci mavisi, klş mavisi, mürekkep mavisi, okyanus mavisi, petrol mavisi, safir mavisi, su mavisi, tropik mavi.

Dilde var olan her şey, yaşantıda ve dolayısıyla doğada var demektir. Dil, bir noktada yaşantıların insan zihnindeki yansımasıdır. İnsan yaşamı, dille asıl gerçekliğini bulur. Yaşantılarımız, düşüncelerimizi oluştururken düşüncelerimiz de yaşantımıza yön verir. Bir toplumun kültürü de yaşantı sonucunda gerçekleşen değerler toplamı olarak tanımlanabilir. Kültürde var olan her unsurun en önemli özelliği de dillendirilmesi, adının konulmasıdır. Renk kültürü de bu süreçlerle gerçekleşen bir söz varlığı alanıdır.

Dil, durağan bir olgu değildir. Bu sebeple insana ve zamana bağlı olarak değişim ve gelişim içerisindedir. Sürekli yeni durumlarla, yeni nesnelerle karşılaşan toplumlar, yeni sözcükler üretme ihtiyacı duyarlar. $\mathrm{Bu}$ süreçte bazı göstergeler kullanımdan düşerken yeni göstergeler de dilin dünyasına girer. Dil, insanın gerçekleştirdiği bir tüketim ve üretim süreci olarak tanımlanabilir. Düşünce dünyasında kavram ve nesnelere ad verme, bir noktada bir bilgi üretimidir. "Bilgi, genel olarak belirtmek gerekirse, insanın biyolojik evrimi; dolaylstyla, doğada zihinsel süreçlerinin gelişimi sonucu edindiği bir kazanımdır. Basit düzlemde her insan gözlediklerinden bir takım sonuçlara giderek 'bilgi' üretebilir. Bu bir farkında olma, ayrımsama, ya da bilme biçimidir." (Büyükkantarcıoğlu, 2006: 19) Bu bağlamda renk adları da bir "farkındalık, ayrımsama ve bilme biçimi” (Büyükkantarcıoğlu, 2016: 19) olarak değerlendirilebilir. Bu ayrımsama biçiminin Türkçede renk adlarına yansıması, geniş bir söz varlığının ortaya çıkış sebebidir: "Özellikle renk tonlarında var olan çeşitlilik ve canlı anlatım, başka dillerde rastlanmayan bir zenginliği ortaya koyar. Örneğin kavuniçi, limonküfü, vişneçürü̈̆̈̈, sütlü kahve, narçiçeği... gibi renk tonları, doğadaki nesnelere dayanılarak ince renk ayırımlarının nasıl dile yansıtıldığını gösterir." (Aksan, 2009: 97-98) Türkçenin söz varlığı açısından renk adlarının belirlenmesi, önem taşımaktadır.

"Renkler üzerine titiz ve son derece ayrnntılı bir çalışma gerçekleştiren Kaymaz (1997: 253) tarafindan Türkiye Türkçesi ve ağızlarında renk bildiren kelimelerin toplam sayısı -pekiştirme sıfatları, benzerlik sifatları, at donları ve fillerden türetilmiş ağarmak, bozarmak, bronzlaşmak, esmerleşmek, göğermek, kararmak, kızıllaşmak, morarmak, neftileşmek, sararmak, turunculaşmak, zümrütlenmek $v b$. renk adları da dahil olmak üzere-Türkiye Türkçesine ait çeşitli sözlükler, yazll eserler ve Derleme Sözlüğü dikkate alınarak 1.447 olarak ifade edilmişstir. Yalnız Türkiye Türkçesi için geçerli olan bu 
rakamın diğer lehçelerde yer alan renk adlarının ilave edilmesiyle artacă̆ gerçektir." (Küçük, 2010: 421)

Var olanla yetinmek, yeni adlandırmalar yapmamak, insanın zihin dünyasına aykırıdır. Bu noktada Türkçe, renk adları açısından sonsuz bir yaratma olanağı sunmaktadır. Türetme, birleştirme, aktarma ve alıntılama yoluyla bugün de yepyeni renk adları oluşturulmaktadır: "Doğasındaki özellikler dolayısıyla doğrudan doğruya tanımlanamayan renkler, dolayl olarak, nesne, meyve veya bitki renklerinden aktarmalar yapılarak, karşıt renklerden, benzetmelerden, eş anlamlardan, zit anlamlardan, açıklık, koyuluk veya bir renge yakınlıklardan yaralanarak, kıyaslamalar yapılarak tanımlanabilmektedir." (Özmen, 2017: 131)

İnsanın dünyasında üretimin artması, gelişen teknoloji, toplumsal değişmeler, renklerin adlandırılmasında önemli etkenler olarak karşımıza çıkmaktadır. Bugün özellikle tüketiciye yönelik tüm alanlarda renklerin insan psikolojisi üzerindeki etkileri de dikkate alınmakta ve oluşturulan markalar, üretilen ürünler, hep renklerin yardımı yoluyla tüketiciye sunulmaktadır. Günümüz dünyasında ürün ve marka çokluğu, insan üzerinde seçim yapma zorunluluğunu da doğurmuştur. Marka değeri denilen durumu oluşturan unsurlardan biri de seçilen renk ve rengin adlandırılmasıdır. Bu bağlamda teknolojik ürünler, giyim, kişisel bakım ve mimari gibi alanlarda renklerin seçimi ve adlandırılmaları üzerinde önemle durulduğu görülmektedir.

Alım satımın olduğu her durum, bir iletişim sürecidir. "Pazarlama iletişimi, işletmelerin tüketicilere mal ve hizmetlerini tanıtmaları amacılla çeşitli pazarlama iletişim araçlarını kullanarak (reklam, satış geliştirme, halkla ilişkiler, kişisel satış, doğrudan pazarlama) gerçekleştirdikleri ikna edici bir iletişim sürecidir." (İçli ve Çopur, 2008: 22) Bu etkileşim ve iletişim sürecinde renklerin adlandırılması da önemli bir pazarlama unsuru olarak işlev görmektedir. $\mathrm{Bu}$ durum, bu alanlarda renklerin ayırımının çoğalmasına, buna bağlı olarak da adlandırmaların çok değişik biçimlerde oluşmasına yol açmıştır. Üretim dünyasına bakıldığında özellikle kadınlara yönelik giyim ve kişisel bakım ürünlerinde daha ayrıntılı, daha etkileyici adlandırmaların kullanıldığı dikkati çekmektedir. Günümüzde özellikle saç ve kumaş boyalarının adlandırılmasının alıcının ilgisini çekecek biçimlerde oluşturulduğu görülmektedir. Bu durum, ürünün hedef kitlesinin cinsiyetiyle ilgilidir. Gizemli kahve, ışıltılı kızıl, altın sarısı, yılbaşı kırmızısı, çekici bakır gibi bağdaştırmalar, alıcının hem görsel hem de işitsel duyularına hitap edecek biçimde gerçekleştirilmektedir. Ayrıca ikiden fazla sözcükle oluşturulan daha ayrıntılı bir anlatımın olduğu bağdaştırmalar da kullanılan yapılar arasındadır: Açık kahve kestane, çok açık derin küllü sarı, altın parıltılı bal, metalik derin mavi gibi. Bu noktada oluşturulan yapılar, Türkçenin zenginliğinin, kavramlaştırma gücünün bir göstergesi olarak değerlendirilebilir. A $\breve{g} a c ̧$ kabuğu, buzlu yeşil, yă̆ yeşili, bulut mavisi, çiğ damlası yeşili, deniz kumu rengi, deniz yeşili, eskimiş beyaz, gül ağacı, ısırgan yeşili, ırmak yeşili gibi örnekler, Türkçenin renk dünyasını daha da zenginleştirmektedir.

Türkçede renklerin adlandırılmasında alıntı sözcükler de kullanılmaktadır. Renk isimleri alanında yabancı sözcükler, geçmişte olduğu gibi bugün de Türkçeye kolay bir geçiş özelliği taşımaktadır:

"Türkiye Türkçesinde renk adlarında yabancılaşma Arapça ve Farsça kelimelerle başlamıştır. Örneğin amber, beyaz, eflatun, esmer, kırmızı, kimyoni, safran, sarabi, zeytuni, zümrüt, zift gibi kelimeleri Arapçaya; abanoz, ates, lacivert, siyah, erguvani, nohudi kelimelerini Farsçaya borçluyuz. Bej, bordo, füme, gri, karmen, krem, safir, siklamen, taba, vermiyon, maron, kadminyum, mimoza, magnezyum, bismark gibi renk adlarını ise Fransızcadan almışız. Bunu ilerleyen yıllarda gri füme, abanoz karası, abanoz siyahı; biftek kırmızısı, karmen kırmızısı, vermiyon kırmızısl; karmen mavisi, kobalt mavisi, mine mavisi, saks mavisi; katran siyahl, sahtiyan siyahl, hareli neftî... gibi her iki unsuru da yabancı kelimeden oluşmuş renk adlandırmaları izlemiştir." (Küçük, 2010: 421)

Turkish Studies, 15(2) 
Günümüzde yabancı sözcüklerle yapılan adlandırmalarda yukarıda ifade edilenlerin yanı sıra "antik, optik, pastel, mat, metalik, naturel, floresan, neon, mint" gibi sözcüklerin de kullanıldığ 1 görülmektedir: Optik beyaz, metalik beyaz, metalik mavi, metalik gri, metalik siyah, neon pembe, neon yeşil, mint yeşil, floresan yeşil, floresan pembe, floresan boncuk mavi, floresan kavuniçi, floresan lila, antik kemik, antik mor, antik mürdüm, antik pembe, antik sarl, antik taba, antik turkuaz, antik yă̆ yeşili, antik yeşil, pastel lila, pastel mavi, pastel pembe, pastel sarl, pastel turuncu, pastel yeşil.

Türkçede renk adları oluşturmada sözcüklerin duygu, tasarım ve çağrışım değerleri de (Aksan, 2009: 52-58) önemli bir etkendir. İletişim değeri taşıyan bu adlandırmalarda genel olarak olumsuz çağrışım ve duygu değeri taşıyan sözcüklerin kullanılmadığı görülmektedir. $\mathrm{Bu}$ değerlendirmeye aykırı olarak tespit edilen tek kullanım ise bir saç boyası rengine ad olarak verilen "timsah gözyaşı" tamlamasıdır.

Renklerin adlandırılmasında özellikle ticari alanda oluşturulan bağdaştırmaların temelinde alıcıyı etkileme yoluyla harekete geçirme isteği vardır. Bu da dilsel iletişimde dilin çağrı işleviyle ilgilidir:

"Dilin çağrıda bulunma işlevinde gerçekleşen ve alıcıya yönelik olan işlevidir. İleti ile alıcı arasındaki ilişkileri tanımlar; çünkü ilke olarak, bu iletişsimin amacı alıcıda bir tepki ve davranışında bir değişiklik yaratmaktır. Şunu da belirtmek gerekir ki, birine (bir alıcıya) seslenirken, örtülü ya da belirtik olarak, amaç hep ondan bir şey istemektir. Verilen bir emir alıcinin ya aklina ya da duygusuna seslenebilir." (Kiran ve Kiran, 2010: 97)

Bugünkü renk adlandırmalarına bakıldığında etkileyici, şiirsel bir dil kullanımının varlığı da göze çarpmaktadır. Bu bağdaştırmalar, şiir dilinin de izlerini taşır. Özellikle sözcüklerin çağrışım ve duygu değerleri, renk adlandırmalarında sıklıkla yararlanılan dil kullanım olanaklarından biri olma özelliğini taşır:

"Etkili dil kullanımı yalnızca şiir dilinde değildir kuşkusuz. Bazen konuşma dilinde, atasözlerinde, deyimlerde, tanitum metinlerinde, sloganlarda ya da duvar yazllarında da benzer dil kullanımlarını görmek olasıdır. Özellikle tanitım metinlerinde şiire ait her türlü anlatımsal özelliklerden yararlanılabilir. Ses öğesi, anlamsal yapılar, sapmalar, biçemsel yapılar, çağrışımsal kullanımlar, kısacası dilin tüm olanakları tanıtım yazllarında sonuna kadar kullanılır." (Günay, 2007: 308)

Bu bağlamda özellikle günümüzde üretim dünyasında oluşturulan renk adlarını tanıtım metni/ başlığl olarak değerlendirmek de yanlış olmayacaktır. Dingin beyaz, derin siyah, cennet mavisi, deli mavi, kış beji, kış mavisi, yılbaşı kırmızısı, sonbahar kızıll, bahar yeşili, hayal pembe, ekim sisi, mistik yeşil, serin lila, saltanat kırmızısl, lavanta esintisi, kızıl büyü, sümbül demeti gibi bağdaştırmalar, etkili dil kullanımı örnekleridir.

Türkçede renk adları, yapısal olarak birleşik isim, isim tamlaması ve sıfat tamlaması biçiminde oluşturulmaktadır. Sıfat tamlaması biçiminde oluşturulan yapıların içerisinde $a c ̧ ı$, orta, koyu, soluk, donuk, yoğun gibi sıfatlarla yapılan renk adlandırmaları, geniş bir söz varlığı oluşturmaktadır. Hemen hemen her rengin derecesinin belirlenmesinde kullanılan bu sıfatların yanı sıra $a c l$, şirin, sıcak, soğuk, yumuşak, gibi duyulara yönelik sıfatlarla oluşturulan renk isimleri de söz konusudur. Ancak bu gibi yapılar, sıfatın gerçek anlamından ziyade çağrışım değerleri üzerinden ad verme işleminin gerçekleştiği bağdaştırmalardır. Derin sıfatı ölçü bildiren bir niteleme sıfatıyken derin mavi yapısında çağrışım değeri yüklenen bir adlandırmaya dönüşmüştür. Dingin beyaz, derin mavi, acı yeşil, keskin kirmızl, yumuşak pembe, şirin pembe, soğuk gri, soğuk açı kumral bu yapılara örnek olarak verilebilir. Son dönemlerde karşılaşılan bir yap1 da yeni sıfatıyla gerçekleştirilen renk adlandırmalarıdır: Yeni siyah, yeni çağıl, yeni beyaz, yeni somon, yeni fildişi, yeni kese kâğıdı gibi. 
Türkçede renk adlandırılmalarında türetme yoluyla oluşturulan sıfatların kullanıldığı yapılarda dikkati çeken bir durum, +(I)mtırak benzerlik ekiyle oluşturulmuş yapıların artık tercih edilmediğidir. Günümüzde daha çok +(I)msI türetme ekiyle oluşturulmuş yapıların kullanılmakta olduğu görülmektedir. Sıfat tamlaması biçiminde oluşturulan bu yapılarda tamlanan unsurun belirttiği rengin tamlayan kısmındaki renge benzerliği ifade edilmektedir. "+(I)msI eki adlara, renk adlarına ve tat bildiren sifatlara gelerek "benzerlik, andırma" anlamı veren sıfatlar türetir." (Korkmaz, 2007: 59) +(I)msI ekiyle yapılan renk adı örnekleri şunlardır: Pembemsi kırmızı, pembemsi mercan, pembemsi turuncu, mavimsi siyah, mavimsi gümüs, kırmızımsı kahverengi, sarımsı kahve, sarımsı yeşil, yeşilimsi mavi.

-Ik / -Uk ekiyle türetilmiş sıfatların kullanıldığı renk adı örnekleri: Açık altın, açık altın sarısı, açık bal kumral, açık başak, açık bej, açık bordo, açık çimen, açık derin küllü sarı, açık elmas sarısı, açık fildişi, açık fuşya, açı gri, açık gül, açık gülkurusu, açık gümüş sarısı, açık haki, açı kahve, açık kahve kestane, açık karamel, açık kese kâğıdl, açık kestane, açık kestane bakır, açık kırmızı, açık kiremit, açık krem, açık kumral, açık kumral bakır, açık kurşuni, açık kül kahverengi, açık lacivert, açık lavanta, açık leylak, açık mavi, açık mercan, açık meşe, açık mine, açık mor, açık nane yeşili, açık papatya, açık pastel gri, açık pembe, açık portakal, açık sarı, açık somon, açık tarçın, açık toz mavi, açık turkuaz, açık turuncu, açı yăg yeşili, açık yeşil, donuk mavi, donuk yeşil, kırık beyaz, kırık fuşya, soluk gök mavisi, soluk kiremit, soluk lacivert, soluk mavi, soluk pembe, soluk siyah, soluk yeşil, uçuk gri, uçuk haki, uçuk pembe, uçuk petrol, uçuk sarı, uçuk su mavisi, uçuk su yeşili, uçuk turuncu, uçuk yeşil, yanık kırmızı, yanık kahve, yanık turuncu.

“-Ik / -Uk eki ünlü ile biten fiil kök ve gövdelerine eklendiğinde kendini gösteren ünlü çarpışmasını önlemek için, araya bir koruyucu ünsüz almadan -I / -U ünlüsünü düşürerek eklenmiştir." (Korkmaz, 2007: 86) Bu şekildeki sıfatlarla oluşturulan yapılara parlak kırmızı, parlak koyu sarı, parlak lal kuzılı, parlak mavi, parlak pembe, yumuşak pembe, soğuk gri örnekleri verilebilir.

+1I / +1U ekiyle oluşturulmuş sıfatların kullanıldığg renk adı örnekleri de şunlardır: Buzlu kahve, buzlu kestane, buzlu kumral, buzlu yeşil, canl yeşil, canlı kırmızl, canlı mavi, canlı mürdüm, canlı turuncu, canlı yeşil, gizemli kahve, ışıltıll bakır, altın parlltılı bal, fosforlu yeşil, frambuazlı çikolata, kirli beyaz, kirli pembe, küllü kumral, küllü pembe.

-mIş / -mUş eki: "Aslında bir slfat-fiil eki olan -mIş /-mUş eki, eskiden beri yapılmış bitmiş işleri gösteren sıfatlar türetmiştir." (Korkmaz, 2007: 100) Bu yolla türetilmiş sifatlarla oluşturulan renk adları, günümüzde az da olsa söz konusudur: Eskitilmiş gümüş, eskimiş mavi, ağartılmış mavi gibi.

-GIn / -GUn sıfat yapım ekiyle elde edilmiş sıfatların kullanıldığı renk adı örnekleri de sinırlıdır: Dingin beyaz, keskin kırmızı.

Günümüzde -(U)n sıfat yapım ekiyle türetilen yoğun sıfatı renk adlarında da kullanılmaktadır. Yoğun bakır, yoğun gri, yoğun küllü, yoğun küllü kestane, yoğun küllü kızll, yoğun mavi, yoğun siyah, yoğun yeşil gibi.

-(y)IcI: Fiile gelerek sıfat yapan bu ekle oluşturulmuş sıfatların kullanıldığı örnekler: Büyüleyici kahve, kışkırtıcı kahve, göz alıcı maun vb.

Renk adları bakımından çok zengin bir sözvarlığına sahip olan Türkçede yaşantıda bulunan doğal ve yapay birçok şey, renk dünyasına aktarılmıştır. Aktarma, renk adı oluşturmada eskiden beri karşımıza çıkan bir yöntemdir. Türkçenin renk dünyası incelendiğinde "Türkçenin kavramları oluşturmada ne ölçüde doğadan yararlandiğı, renk adlarında doğrudan doğruya çevredeki nesnelere dayanan aktarmalarla adlandırmaya gittiği açık olarak ortaya çıkacaktır." (Aksan, 
2018: 159-160) Aktarmaların renk adı oluşturmada kolaylık sağlaması, bu yolun tercih edilme sebebidir. Bu yaklaşım da şöyle açıklanabilir:

"Aktarımların gerçekleşmesini sağlayan belki de en yaygın neden, yeni sözcük (gösterge) bulma hızımızla ögrenme (bilme, buluş vb.) hızı arasındaki büyük açıktır. Her yeni göndergeye yeni bir gösteren bulunabilmesinin olanaksızlı̆̆l da, eldeki sözcüklerin anlamca genişletilmesini getirmiştir. Aktarımlar, göstergelerde anlamsal boyutta iki önemli sonuç doğurur: Göstergelerin kimileri, kullanıcıların öznelliğinin izini taşırken, kimileri toplumsal konumunda nesnel gösterge özelliğine kavuşur.” (Uğur, 2007: 168)

Günümüzde kullanılan ve aktarma yoluyla oluşturulan renk adları da şöyle örneklendirilebilir:

Yer adlarının kullanıldığı yapılar: Alaçatı, Avanos, Amazon, Bodrum mavisi, Göreme, İzir mavisi, İztuzu, Ege mavisi, Afrika beyazı, Afrika yeşili, Bahama beyazı, Brezilya kahvesi, Paris pembesi, Mostar sarısı, Kahire kahvesi, Harran, Nil yeşili, Venedik sarlsı, Tokyo incisi, Tibet yasemini, Ihlara, Halikarnas, Sicilya, Uludağ çamı, Verona pembesi.

Bitki adlarının (baharat, meyve, ağaç, çiçek) kullanıldığı yapılar: Safran, zerdeçal, hardal sarısı, köri, biber, biberiye, ceviz, hurma, bambu yeşili, çam yeşili, çam kokusu, nane yeşili, başak, yulaf, yulaf beji, gül rengi, gülkurusu, papatya sarısl, begonya, lavanta, leylak, orkide moru, ortanca, zambak moru, krizantem, ayçiçeği, ayçekirdeği, şeftali, vişneçürüğü, vişneli klzıll, portakal, nar, turunç, mango, kivi, kestane, karadut, böğ̈̈rtlen vb.

Yiyecek ve içecek adlarının kullanıldığı yapılar: Çikolata, sütlü kahve, sıcak çikolata, susaml akide, şampanya, naneli akide vb. Bu bağlamda çikolata, sütlü kahve, şampanya gibi örnekler, genelleşmiş bir gösterge özelliği taşırken yeni oluşturulan bağdaştırmalar daha sınırlı bir kullanım özelliği taşımaktadır: Frambuazlı çikolata, badem ezmesi vb.

Doğa olaylarının adlarının kullanıldığı yapılar: Ekim sisi, çı̆̆g, çiğ, çiğ damlası yeşili, buhar, bulut, yağmur ormanı, buz beyazı, buzul yeşil, kar, yakamoz, boran, imbat, sam yeli, meltem, firtına $v b$.

Mevsim adlarının kullanıldığı yapılar: Bahar tozu, bahar yeşili, güz gülü, yaz güneşi, kış güneşi, kuş beji, kuş bordosu, kış mavisi, sonbahar kızıll, güz.

Zaman belirleyici adların kullanıldığı yapılar: Gün batımı, bağ bozumu, gece yarısı.

Tarihsel dönem adlarının kullanıldığı yapılar: Saltanat kırmızısı, barok beji.

Meslek adlarının kullanıldığı yapılar: Asker yeşili, avcı yeşili.

Hayvan ve hayvanlara ait organ adlarının kullanıldı̆̆ı yapılar: Fildişi, bizon, somon, devetüyü, civciv sarısl, flamingo pembesi, vizon, ördekbaşı yeşili.

Doğada var olan değerli maden ve taşların adları da renklerin adlandırılmasında kullanılmaktadır: Altın, bakır, elmas sarısı, bakır, krom, bronz, safir mavisi, inci mavi, akik, yakut kızıl, lal, zümrüt yeşili, yeşim, turkuaz, ametist, amber, mercan kırmızl, opal vb.

\section{Sonuç}

Doğada var olan renkler, insan için her dönemde değer yüklenen birer gösterge olmuştur. İnsanın yaşama biçimi, doğayı algılama biçimiyle koşutluk gösterir. Düşünen, konuşan ve biçimlendiren bir yaradılışa sahip olan insanoğlu, renkleri de doğadan almış, biçimlendirmiş, anlamlandırmış ve yaşamına katmıştır. İnsan için yaşamın temel koşulu doğaya ayak uydurabilmek, doğayı kendi ihtiyaçları doğrultusunda kullanabilmektir. Tarih boyunca insanoğlu, ürettiği bilgiyi doğayı gözlemleyerek elde etmiştir. Dil de bu bağlamda bilgi üretiminde en önemli 
unsurdur. Anlamlandırma; algılama ve adlandırma süreçleriyle gerçekleşir. İnsanoğlu, karşılaştığ1 kavram ve nesnelere ad vererek anlamlı bir duruma getirir ve onu kendi dünyasına katar. $\mathrm{Bu}$ adlandırmalar, çeşitli biçimlerde gerçekleşebilir.

Dilin gereksinimi, insanın gereksinimidir. İnsanın dünyasında ne varsa onun adlandırılması, anlamlandırma noktasında insanın doğası gereğidir. Bu da, dilin sürekli gelişim ve değişim içerisinde olması sonucunu getirmektedir. Doğada dolayısıyla dilde var olan bir ulam da renklerdir. Renklerin birer dilsel gösterge olmaları da diğer göstergelerle aynı süreçleri içerir. Dilde var olan her gösterge, bir kavram ya da nesneye ve insanın onlara yaklaşımına işaret eder. Söz varlığı da böylece gerçekleşir. Temelde bireyin izini taşıyan dilsel göstergeler, uzlaşım ve kullanım sonucu toplumsal olma özelliği kazanır.

Türkçede kavram ve nesnelere ad verme; türetme, birleştirme, aktarma ve alıntılama yoluyla gerçekleşmektedir. Türkçe, renk adları açısından zengin bir söz varlığına sahiptir. Bu söz varlığında, Türkçe yapıların yanı sıra yabancı kökenli sözcüklerle oluşturulan yapıların da yer aldığı görülmektedir. Türkçenin somutlaştırma özelliği, renk adlandırmalarında da karşımıza çıkmaktadır. Ana renk üzerinden yapılan ayrıntılı adlandırmalar, bugün de geçmişte olduğu gibi gerçekleşmektedir. Yaşamın değişmesi, yeni kavram ve nesnelerin ortaya çıkması ve bunların adlandırılması gerekliliği, renkler açısından da yepyeni bağdaştırmaların ortaya çıkmasını sağlamaktadır. $\mathrm{Bu}$ çalışmada Türkiye Türkçesinde günümüzde kullanılan renk adları, belirli kullanım alanlarından hareketle (giyim, kişisel bakım, kumaş, iç ve dış cephe boyaları) belirlenmeye çalışılmıştır. Renklere verilen adların oluşum biçimleri üzerinde durulmuştur. Çalışmada yeşil renginin ton ayrımını belirten günümüzde kullanımda olan yaklaşık 100 adlandırma tespit edilmiştir. Bu sayı, sadece bu çalışmayla elde edilen bir veridir. Türkçede yeşilin ton ayrımının çokluğu, yeşilin Türkler için önemli bir renk olduğunun bir göstergesidir. Mavi ile ilgili adlandırmaların sayısı ise yaklaşı 70 olarak tespit edilmiştir. Bu da gök renginin (mavinin) Türk kültüründeki varlığının dile yansımasıdır. Bu adlandırmalar, Türkçenin renk dünyasınının zenginliğinin birer göstergesidir.

Türkçede renk adlandırılmalarında çok farklı bağdaştırmalarla karşılaşılmaktadır. Örneğin bir mevsim adı olan sonbahar sözcüğünün bugün bir renk adı olarak kullanıldığı da görülmektedir. Bir bitki adı olan yulaf sözcüğü, yulaf beji yapısıyla bir renk adına dönüşebilmektedir. Yine, vaha, buhar, ekim sisi, eskimiş beyaz gibi renk adları da ilgi çekici yapılardır. Sünger taşı, Tibet yasemini, kese kâğıld, fes rengi, çı̆̆, yosun, doğal hasır, çöl kahvesi, dantel, güz gülü, kaktüs çiçeği, perçem mavi, ay ışı̆̆l kahvesi, inci, ladin, okyanus gibi örnekler de Türkçenin renk dünyasında yerlerini almıştır. Ancak bu tür renk adları, daha sınırlı bir kullanım alanına sahiptir. Bu yapıların genelleşmemesi, yayılma alanlarının sınırlı olması, sadece bir ürünün rengine ad olarak verilmeleri sebebiyledir. Elbette bu gibi göstergelerin kullanım alanları genişledikçe genelleşmeleri de söz konusu olabilecektir. Bu bağlamda bu adlandırmaların hangilerinin kalıcı, hangilerinin geçici gösterge olacaklarına zaman içerisinde ihtiyaca ve kullanıma bağlı olarak toplum karar verecektir. Ancak, kullanım alanları sınırlı da olsa bu yapılar, Türkçenin söz varlığında yerlerini almışlardır.

Çalışmada renk adlarının bedirlenmesi için tarama yapılan giyim markaları: LCW, Koton, Mango, Pull\&Bear. Saç boyası markaları: Baco, Blondme, Borthe, Nevacolor, Koleston, Pure Color, İgora, Palette, Wella, Garnier, İnoa, Jamaican Jeans Color, Goldwell. Kumaş boyaları: Cadence. İç ve dış cephe boyaları: Marshall Boya, Dyo, Casati, Filli Boya. Çalışmada tespit edilen renk adları, alfabetik sıralamayla verilmiştir. Renk adlarının yazımı noktasında Güncel Türkçe Sözlük (TDK) esas alınmıştır. Sözlükte ve yazım kılavuzunda bulunmayan bazı alıntı sözcüklerin yazımında ise genel kullanım biçimleri esas alınmıştır.

\section{Günümüzde Kullanılan Renk Adı Örnekleri}

A. Acı yeşil, açık altın, açık altın sarısı, açık bal kumral, açık başak, açık bej, açık bordo, açık çimen, açık derin küllü sarı, açık elmas sarısı, açık fildişi, açık fuşya, açık gri, açık gül, açık 
gülkurusu, açık gümüş sarısı, açık haki, açık kahve, açık kahve kestane, açık karamel, açık kese kâğıdı, açık kestane, açık kestane bakır, açık kırmızı, açık kiremit, açık krem, açık kumral, açık kumral bakır, açık kurşuni, açık kül kahverengi, açık lacivert, açık lavanta, açık leylak, açık mavi, açık mercan, açık meşe, açık mine, açık mor, açık nane yeşili, açık papatya, açık pastel gri, açık pembe, açık portakal, açık sarı, açık somon, açık tarçın, açık toz mavi, açık turkuaz, açık turuncu, açık yağ yeşili, açık yeşil, adaçayı, Afrika beyazı, Afrika yeşili, ağaç kabuğu, ağartılmış mavi, akaju, akaju kızıl, akik, akrilik beyaz, akvaryum, al, Alaçatı, altın, altın çikolata, altın karamel, altın kestane, altın parıltılı bal, altın parıltılı çikolata, altın pırıltılı kahve, altın sarısı, altuni, alüvyon, amazon, amber, amber kahve, ametist, andız, Antep fistığı, antik altın, antik bakır, antik beyaz, antik çikolata, antik gri, antik gümüş, antik kahve, antik kemik, antik mor, antik mürdüm, antik pembe, antik sarı, antik taba, antik turkuaz, antik yağ yeşili, antik yeşil, antrasit, antrasit gri, aqua marin, aqua mavi, arduvaz gri, asil lila, asker yeşili, aşk alevi, ateş kızılı, ateşî pembe, Avanos, avcı yeşili, ayça, ay çekirdeği, ay ışığı, ay 1şığı kahvesi, ayçiçeği, ayçiçeği sarısı, az sütlü çikolata.

B. Badem, badem beji, badem ezmesi, bağ bozumu, Bahama beyazı, bahar tozu, bahar yeşili, bakır, bakır akaju, bakır kahve, bakır sarısı, Balat, balbadem, bal beji, bal buğu, balçiçek, balmumu, bal sarısı, balköpüğü, bal peteği, balsa, başak, bambu, bambu yaprağı, bambu yeşili, barok, barok beji, bayrak kırmızısı, bebek mavisi, bebek pembesi, bebek yeşili, begonya, bej, belce beji, beliz, beşibiryerde, beyaz, beyaz menekşe, biber, biber kızılı, biberiye, bisküvi beji, bitter çikolata, bizon, Bodrum mavisi, boncuk mavi, boran, bordo, boz gri, boz kahve, bozkır, böğürtlen, böğürtlen siyahı, Brezilya kahvesi, briket, bronz, bronz bej, bronz kakao, bronz kızıl, buğday, buğu lila, buhar, bulut, bulut mavisi, Burgonya şarabı, buz beyazı, buz gümüşü, buz mavisi, buz rengi, buz yeşili, buzlu kahve, buzlu kestane, buzlu kumral, buzlu yeşil, buzul, buzul gri, buzul yeşil, büyüleyici kahve.

C. Camgöbeği, camgöbeği mavi, cam yeşili, canlı kırmızı, canlı mavi, canlı mürdüm, canlı turuncu, canlı yeşil, cennet mavisi, ceviz, ceviz yeşili, Cezayir menekşesi, civciv sarısı.

Ç. Çağla yeşili, çakı1, çakıl grisi, çakıl taşı, çakıllı kum, çam kokusu, çam yeşili, çapa mavi, çayır yeşili, çekici bakır, çığ, çiftlik yeşili, çiğ beyaz, çiğ damlası, çiğ damlası yeşili, çikolata, çikolata kahve, çilek kırmızısı, çim yeşili, çimen, çimen yeşili, Çin mavisi, çingene pembesi, çisenti, çit yeşili, çivit mavisi, çok açık derin küllü sarı, çöl beyazı, çöl kahvesi, çöl kumu, çömlek.

D. Dağ kristali, damla sakızı, dantel, defne, defne yeşili, deli mavi, deniz kabuğu, deniz kumu rengi, deniz mavisi, deniz tuzu, deniz yeşili, derin mavi, derin siyah, derya, devetüyü rengi, dingin beyaz, dingin mavi, doğal hasır, doğal sarı, domates kırmızısı, donuk mavi, donuk yeşil, dore sarı, duman, duman grisi, duman mavisi.

E. Ebegümeci, eflatun, efsanevi Türk kahvesi, Ege mavisi, egzotik kızıl, ekim sisi, ekin, ekinezya gri, ekru, ekstra koyu kahve, elegan kahve, elektrik mavisi, elma şekeri, elma yeşili, elmas sarısı, erguvan, erik, esinti, eskimiş beyaz, eskitilmiş gümüş.

F. Fes rengi, fındık beji, fındık kakao, fındık sarısı, fındıkkabuğu, fırtına, fıstık, fıstık yeşili, fildişi, filiz, filizî koyu, firuze, flamingo, floresan boncuk mavi, floresan kavuniçi, floresan lila, floresan mavi, floresan pembe, floresan sarı, floresan yeşil, fosforlu yeşil, frambuazlı çikolata, fuşya, fuşya çiçeği, füme, füme gri, füme sarı.

G. Gardenya, gece kızılı, gece mavisi, gece yarısı, gizem, gizemli kahve, gold, gök mavisi, gökçe, gökyüzü, gökyüzü mavisi, gölge gri, gölgem, Göreme, göz alıcı kahve, göz alıcı maun, gözde mavi, granit inci, gri, gri beyaz, gri mavi, gri pembe, gri yeşil, gülce, gül ağacı, gül kızılı, gül pembe, gülkurusu, gül şeker, gümüş, gümüş bej, gümüş gri, gümüş sarısı, günebakan, güneş, gün batım1, gün 1şığ1, gün 1şığı kestane, güneş sarıs1, güz, güz gülü.

H. Haki, haki yeşil, Halikarnas, hardal, hardal sarısı, hareli, Harran, havai mavi, Havana, hayal pembe, hercai, Hitit, humus, hurma. 
I. Ihlamur, ıhlamur yeşili, Ihlara, 1lgım, ırmak yeşili, ısırgan yeşili, ışı pembe, 1şıltılı bakır, 1ş1ltılı çikolata.

İ. İmbat, ince kum, inci, inci mavisi, inci sarı, indigo mavisi, istiridye kremi, İzmir mavisi, İztuzu.

J. Jamaican moru.

K. Kadife kahve, Kahire kahvesi, kahve, kahve bakır, kahve kestane, kahve köpügü̈, kakao, kaktüs çiçeği, kamuflaj yeşili, kan kırmızı, kanyak, kanyon, kapuçino, kar tanesi, karadut, karamel, karamel kumral, Karayip mavisi, kardelen, karnaval, Kartepe, kaşmir, kaşmir kumral, kavruk turuncu, kaya, kayısı çiçeği, kavun, kavun sarısı, kavuniçi, kayısı beyazı, kayısı turuncu, kehribar, kehribar sarısı, kekik yă̆ı, kement, kemik, kemik beyazı, kereviz, kese kâğıdı, keskin kırmızı, kestane, kestane kızılı, kestane krem, keten, kına, kına yeşili, kırık beyaz, kırık fuşya, kırmızı, kırmızımsı kahverengi, kış beji, kış bordosu, kış güneşi, kış mavisi, kışkırtıcı kahve, kızıl, kızıl büyü, kızıl cazibe, kızıl çikolata, kızıl kahve, kızıl kor kızıl, kızıl kumral, kızıl sarı bakır, kızıl viyole, kil rengi, kiremit, kiremit kahve, kirli beyaz, kirli pembe, kivi yeşili, klasik açık meşe, klasik altın, klasik ceviz, klasik koyu meşe, klein mavisi, kobalt mavi, kor kızıl, kot mavisi, koyu altın, koyu bej, koyu camel, koyu eflatun, koyu gri, koyu haki, koyu indigo, koyu kahve, koyu kahverengi, koyu kestane, koyu kırmızı, koyu kızıl, koyu kiremit, koyu krem, koyu kumral, koyu kumral dore, koyu kurşuni, koyu lacivert, koyu mavi, koyu mercan, koyu meşe, koyu mor, koyu nar, koyu pembe, koyu petrol, koyu sarı, koyu sarı dore, koyu somon, koyu su yeşili, koyu şişe yeşili, koyu turkuaz, koyu turuncu, koyu yağ yeşili, koyu yeşil, koyu zeytin, koza, kozmik, kömür karası, köpük, körfez, köri, krem, krem beyaz, krem karamel, krem sarı, kristal gri, krizantem, krom, krom sarısı, kum, kum beyazı, kum beji, kum taşı, kumral dore, kumral irize bakır, kumral kızıl bakır, kumral tütün, kumral yoğun küllü, kumsal, kurdele pembesi, kurşuni, kurşun siyah, kuzey, küf yeşili, kül, kül bulutu, kül grisi, kül kestane, küllü açık sarı, küllü çok hafif sarı, küllü kumral, küllü pembe.

L. Lacivert, ladin, lagun mavi, lal, latte, lavanta, lavanta esintisi, leylak, leylak çiçeği, lila, lilyum pembe, limon, limonata, ,limon çiçeği, limon sarısı, limon yeşili, lüle taşı.

M. Makine gri, makine kırmızısı, makine mavisi, makine yeşili, Malta, mandalina, mango, manolya, marin mavi, masal, masal pembesi, mat beyaz, mat kırmızı, mat mavi, mat pembe, mat sarı, mat siyah, mat turkuaz, mat turuncu, mat yeşil, maun, mavi siyah, mavimsi gümüş, mavimsi siyah, meltem, menekşe, menekşe mavisi, menekşe moru, mentol buğusu, melisa, mercan, mercan kırmızı, mercan pembesi, metalik açık yeşil, metalik ametist, metalik bakır, metalik beyaz, metalik deniz mavisi, metalik elektrik yeşili, metalik fuşya, metalik gri, metalik gümüş, metalik jade, metalik kırmızı, metalik kiraz, metalik koyu bakır, metalik koyu viyola, metalik lila, metalik mavi, metalik mercan, metalik pembe, metalik petrol yeşili, metalik sarı, metalik siyah, metalik viyola, metalik yeşil, metalik yeşim, Milano, mimoza, mine, mine mavi, mint yeşili, minyon sarısı, misket limonu, mistik yeşil, mor, mor lila, mor salkım, Mostar sarısı, mum 1şı̆̆ı, muson, mürdüm, mürdüm kızıl, mürekkep mavisi.

N. Naneli akide, nane limon, nane şekeri, nane yeşili, Napolyon mavi, nar, nar kırmızısı, nar kızılı, narçiçeği, natürel kahve, neftî, neftî yeşil, nektar, Nemrut, neon mint yeşili, neon pembe, Nil kıyısı, Nil yeşili.

O. Oksit kırmız1, oksit sarı, okyanus, okyanus mavisi, opal, opalit, optik beyaz, orkide, orkide moru, orman, orman yeşili, ortanca, orta bakır, orta camel, orta gri, orta haki, orta kahve, orta kestane, orta kumral küllü, orta mavi, orta pembe, orta sarı, orta yeşil.

Ö. Ördekbaşı yeşili, özel kum beji.

P. Pamuk, pamuk şekeri, papatya sarısı, parlak kırmızı, parlak koyu sarı, parlak lal kızılı, parlak mavi, parlak pembe, papatya, Paris pembesi, parlament, parlament mavisi, pastel 
kahverengi, pastel lila, pastel mavi, pastel pembe, pastel sarı, pastel turuncu, pastel yeşili, patlıcan, patlıcan moru, pembemsi kırmızı, pembemsi mercan, pembemsi turuncu, perçem mavi, petek, petrol, petrol mavisi, petrol yeşili, Pisa, platin, platin grisi, platin sarısı, porselen mavisi, portakal, prenses pembe, pudra, pudra kahve, pudra mor, pudra pembe, pudra yeşili.

R. Rezene, romantik, romantik pembe, rose, rüzgâr.

S. Safir, safir mavisi, safran, safran sarıs1, sahra beji, sahra sarıs1, saks mavisi, salep, saltanat kırmızısı, saman sarısı, sam yeli, saray, sardunya, sarı, sarı altın kahve, sarımsı kahve, sarımsı pembe, sarımsı yeșil, sarmașık yeșili, sedef, seramik, serin lila, sıcak çikolata, sıcak kızıl, sıcak turuncu, sığla, sıklamen, sınav sarısı, Sicilya, silver, sis, sis gri, siyah, siyah üzüm reçeli, soft kırmızı, soft yeşil, soğan kabuğu, soğuk açık kumral, soğuk gri, soluk gök mavisi, soluk kiremit, soluk lacivert, soluk mavi, soluk pembe, soluk siyah, soluk yeşil, som altın, somon, sonbahar, sonbahar kızılı, su mavisi, su yeşili, sultan bakırı, sumak, susamlı akide, sümbül demeti, sünger taş1, süt beyazı, sütlü çikolata, sütlü kahve.

Ş. Şampanya, şampanya köpüğ̈̈, şarap, şarap bordo, şarap kırmızısı, şarap kızılı, şebnem, şeftali, şeftali aroma, şeftali çiçeği, şeker pembe, şelale, şirin pembe, şişe yeşili.

T. Taba, taksi sarısı, tarçın, tarçın bakır, tarçın kahve, tarçınlı kek, taş, ten pembesi, ten rengi, Tibet yasemini, timsah gözyaşı, titan sarısı, Tokyo incisi, toprak sarı, toz gri, tozpembe, traktör kırmızı, tramisu, tropik, tropik mavi, tuğla rengi, Tuna yeşili, turkuaz, turkuaz coşkusu, turkuaz mavisi, turkuaz yeşili, turuncu, turunç, türbe yeşili, Türk kahvesi, tütün, tütün kahvesi.

U. Uçuk gri, uçuk haki, uçuk pembe, uçuk petrol, uçuk sarı, uçuk su mavisi, uçuk su yeşili, uçuk turuncu, uçuk yeşil, ufuk grisi, ultra doğal sarı, Uludağ çamı, uzay gri.

V. Vaha, vahşi kızıl, vanilya, vanilya çiçeği, vanilya sarısı, Venedik sarısı, venge, Verona yeşili, vigo pembe, viski, vişne, vişne kızılı, vişneçürüğü, vişneli turta, vizon, volkan gri.

Y. Yaban gülü, yabani kekik, yağmur ormanı, yağ yeşili, yakamoz, yakut kızıl, yalı pembe, yalın, yanık kahve, yanık kırmızı, yanık turuncu, yaprak, yaprak yeşili, yasemen, yavruağzı, yayla yeşili, yaz güneşi, yaz kırmızısı, yeni çağıll, yeni fildişi, yeni kese kâğıdı, yeni siyah, yeni somon, yeni yavruağzı, yeşil, yeşil su, yeşilimsi mavi, yeşim, yılbaşı kırmızısı, yıldız, yoğun bakır, yoğun gri, yoğun küllü, yoğun küllü kestane, yoğun küllü kızıl, yoğun mavi, yoğun siyah, yoğun yeşil, yonca, yonca yeşili, yosun, yosun yeşili, yulaf, yulaf beji, yumuşak pembe.

Z. Zambak moru, zemheri, zengin bakır, zerdeçal, zeytin yeşili, zümrüt, zümrüt yeşili.

\section{Kaynakça}

Aksan, D. (2004). Dilbilim ve Türkçe yazıları. İstanbul: Multilingual.

Aksan, D. (2009). Anlambilim anlambilim konuları ve Türkçenin anlambilimi. Ankara: Engin.

Aksan, D. (2018). Türkçenin sözvarlı̆̆ı. Ankara: Bilgi Yayınevi.

Bayraktar, N. (2014). Türkçe yeşil renk adının biçim, anlam ve kavram alanına tarihsel bir bakış. Journal of Language and Linguistic Studies, 10(1),179-193.

https://dergipark.org.tr/tr/download/article-file/104816

Bayraktar, N. (2017). Editör: Emine Gürsoy Naskali. Renk kitabl, Türkçede kişi adlarında renk adları. İstanbul: Kitabevi Yayınları.

Büyükkantarcıoğlu, N. (2006). Toplumsal gerçeklik ve dil. İstanbul: Multilingual. 
Doğan, N. (2015). Türkiye Türkçesi söz varlığının yeni renkleri ad bilimsel bir inceleme. Dede Korkut Uluslararası Türk Dili ve Edebiyatı Araştırmaları Dergisi, sayı: 7.

http://www.dedekorkutdergisi.com/Makaleler/210566028_DO\%C4\%9EAN,\%20nuh.pdf

Ercilasun, A.B. (2016). Türk kağanlı̆̆ı ve Türk bengü taşları. İstanbul: Dergâh Yayınları.

Ergin, M. (2016). Dede Korkut Kitabı 1-2. Ankara: TDK.

Genç, R. (1996). Yayına Hazırlayanlar: Sadık Tural, Elmas Kılıç. Nevruz ve renkler, Türk düsüncesi, davranışı ve hayatında renkler ve sarı, kırmızı, yeşil. Kongre ve Sempozyum Bildirileri Dizisi, Sayı: 7. Ankara: Atatürk Kültür Merkezi Yayını, Sayı: 116. ss. 41-48.

Günay, V. D. (2007). Metin bilgisi. İstanbul: Multilingual.

Günay, V. D. (2013). Dil ve iletişsim, İstanbul: Papatya.

Hey'et, C. (1996). Yayına Hazırlayanlar: Sadık Tural, Elmas Kılıç. Nevruz ve renkler, Türklerin tarihinde renklerin yeri. Kongre ve Sempozyum Bildirileri Dizisi, Sayı: 7. Ankara: Atatürk Kültür Merkezi Yayını, Sayı: 116. ss.55-61.

İçli, G. E. ve Çopur, M. E. (2008). Pazarlama iletişiminde renklerin rolü. Trakya Üniversitesi Sosyal Bilimler Dergisi, Cilt 10 Say1 1, 22-33. https://dergipark.org.tr/tr/download/articlefile/321697

Kıran, Z. ve Kıran, A. (2010). Dilbilime giriş. Ankara: Seçkin.

Korkmaz, Z. (2007). Türkiye Türkçesi grameri şekil bilgisi. Ankara: TDK.

Küçük, S. (2010). Türkiye Türkçesinde renk adları ve özellikleri. Uluslararası Sosyal Araştırmalar Dergisi. The Journal of International Social Research Volume 3 / 10 Winter. http://www.sosyalarastirmalar.com/cilt3/sayi10pdf/kucuk_salim.pdf

Nerimanoğlu, K.V. (1996). Yayına Hazırlayanlar: Sadık Tural, Elmas Kılıç. Nevruz ve renkler, Türk dünya bakışında reng. Kongre ve Sempozyum Bildirileri Dizisi, Sayı: 7. Ankara: Atatürk Kültür Merkezi Yayını, Sayı: 116. ss. 63-73.

Ögel, B. (1998). Türk mitolojisi (kaynakları ve açıklamaları ile destanlar). 1.Cilt, 3. Baskı. Ankara: Türk Tarih Kurumu Yayınları.

Özmen, M. (2017). Türkçede renkleri tanımlama sorunu. Çukurova Üniversitesi Türkoloji Araştırmaları Dergisi, Cilt 2, Say1 2. https://doi.org/10.32321/cutad.352091

Saussure, F.de. (1998). Çev: Vardar, B. Genel dilbilim dersleri. İstanbul: Multilingual.

Uğur, N. (2007). Anlambilim sözcüğ̈̈n anlam açılımı. İstanbul: Doruk Yayımcılık.

Yıldırım, E. (2012). Türk kültüründe renkler ve ifade ettikleri anlamlar. Yayımlanmamış yüksek lisans tezi, İstanbul Üniversitesi Sosyal Bilimler Enstitüsü, İstanbul.

http://acikerisim.istanbul.edu.tr/bitstream/handle/123456789/31300/49335.pdf? sequence=1

https://sozluk.gov.tr/

Turkish Studies, 15(2) 